\title{
MENINGKATKAN HASIL BELAJAR IPA SUBTEMA MANFAAT ENERGI MELALUI MODEL PEMBELAJARAN MAKE A MATCH
}

\author{
Ivan Subandriyo ${ }^{1}$, Suhandi Astuti ${ }^{2}$ \\ 1,2, Jurusan Pendidikan Dasar, Universitas Kristen Satya Wacana, Salatiga \\ e-mail: studiorimba@gmail.com ${ }^{1}$, suhandi.astuti70@gmail.com²
}

\begin{abstract}
ABSTRAK
Latar belakang masalah pada penelitian ini adalah Pembelajaran yang dilakukan guru sebelumnya kurang efektif terhadap hasil belajar siswa. Penyampaian materi yang diberikan guru masih kurang menarik perhatian siswa sehingga berdampak pada hasil pencapaian belajar. Untuk dapat meningkatkan hasil belajar, siswa memerlukan modal pembelajaran untuk memahami materi pembelajaran IPA. Tujuan penelitian ini adalah meningkatkan hasil belajar subtema manfaat energi menggunakan model pembelajaran make a match pada siswa kelas 4 SDN Campuranom Kabupaten Temanggung Semester 1 Tahun Pelajaran 2018 / 2019. Jenis penelitian ini adalah penelitian tindakan kelas (PTK) dengan dua siklus. Subyek penelitian ini adalah siswa kelas 4 SDN Campuranom Kabupaten Temanggung yang terdiri dari 29 siswa. Metode penelitian mengacu pada pengembangan siklus Kemmis dan Tagart. Hasil penelitian pembelajaran IPA dengan model pembelajaran Make a Match dapat meningkatkan hasil belajar siswa kelas 4 SDN Campuranom semester 1 Tahun Pelajaran 2019/2020. Hal tersebut didasarkan pada rerata nilai prasiklus sebesar 65,17 dengan ketuntasan belajar $37,93 \%$ meningkat menjadi 68,1 dengan persentase ketuntasan $62,07 \%$ pada siklus 1; selanjutnya setelah dilakukan perbaikan pada siklus 2 rata-rata hasil belajar meningkat menjadi 77,07 dengan persentase ketuntasan mencapai $82,76 \%$.
\end{abstract}

Kata Kunci : Model Make a Match, Pembelajaran IPA, Hasil Belajar.

\begin{abstract}
The background of the problem in this study is that the learning done by the teacher was less effective in student learning outcomes. Submission of material provided by the teacher still does not attract the attention of students so that it has an impact on the results of learning achievement. To be able to improve learning outcomes, students need learning capital to understand science learning materials. The purpose of this study is to improve the learning outcomes of the energy benefit subtheme using make a match learning model in grade 4 students of SDN Campuranom Temanggung Regency Semester 1 in 2018/2019 Academic Year. This type of research is a Classroom Action Research (CAR) with two cycles. The subjects of this study were Grade 4 students of SDN Campuranom Temanggung Regency which consisted of 29 students. The research method refers to the development of the Kemmis and Tagart cycles. The results of science learning research with the Make a Match learning model can improve the learning outcomes of 4th grade students of SDN Campuranom semester $12019 / 2020$ Academic Year. This is based on the average pre-cycle value of 65.17 with $37.93 \%$ learning completeness increasing to 68.1 with $62.07 \%$ completeness in cycle 1 ; then after making improvements in cycle 2 the average learning outcomes increased to 77.07 with the percentage of completeness reaching $82.76 \%$.
\end{abstract}

Keywords : Model Make a Match, Science Learning, Learning Outcomes 


\section{Pendahuluan}

Dari pengamatan lapangan yang dilakukan penulis di SDN Campuranom menunjukkan bahwa siswa masih mengalami kesulitan dalam pembelajaran tematik. Siswa mengalami kesulitan dalam memahami konsep-konsep dalam belajar tematik yang berdampak pada kesulitan siswa dalam mengerjakan soal-soal evaluasi sehingga hasil belajar kognitif, psikomotor dan afektif yang didapatkan siswa masih rendah. Hal ini disebabkan oleh penguasaan metode pembelajaran oleh guru yang masih rendah sehingga kurang menarik minat siswa untuk memahami konsep belajar tematik. Berdasarkan permasalahan diatas sangat diperlukan solusi yang tepat untuk menarik minat siswa dalam belajar tematik agar prestasi belajar siswa juga meningkat.

Di sisi lain ada pula salah satu model pembelajaran yang dapat diterapkan adalah model pembelajaran Make a Match. Model pembelajaran Make a Match dinilai mampu meningkatkan aktivitas dan hasil belajar karena model pembelajaran tersebut dapat digunakan dalam bentuk permainan sehingga peserta didik menjadi lebih antusias dalam belajar. Sutarniyati (2016), meneliti peningkatan motivasi belajar siswa menggunakan model make a match pada pelajaran IPA kelas V, dengan hasil akhir motivasi belajar IPA siswa dalam kategori sangat baik (89\%).

Berdasarkan permasalahan di atas dan hasil penelitian sebelumnya yang telah dipaparkan, penulis sebagai peneliti hendak merancang penelitian yang berjudul: "Meningkatkan Hasil Belajar IPA Tema Selalu Berhemat Energi Menggunakan Model Pembelajaran (MP) Make a Match (MM) pada Siswa Kelas IV SDN Campuranom Kabupaten Temanggung Semester 1 Tahun Pelajaran 2019 / 2020." Peneliti berharap melalui penelitian tindakan kelas menggunakan Model Pembelajaran Make a Match dapat meningkatkan hasil belajar siswa Kelas IV SDN Campuranom Kecamatan Bansari Kabupaten Temanggung.

Peningkatan Kualitas Pembelajaran IPA Melalui Model Make A Match Berbantuan Media Papan Flanel Pada Siswa Kelas IV SDN Pudakpayung 02. Jasmini (2015). Universitas Negeri Semarang. Hasil penelitian menunjukkan bahwa: (1) Keterampilan guru pada siklus I rata-rata pencapaian skor sebesar 26,5 (baik) dan meningkat pada siklus II dengan rata-rata sebesar 32 (sangat baik); (2) Aktivitas siswa ada siklus I rata-rata pencapaian aktivitas siswa sebesar 22,12 (baik) dan meningkat pada siklus II dengan ratarata sebesar 29,7 (sangat baik); (3) Hasil belajar dengan rata-rata ketuntasan klasikal pada siklus I yaitu $52,3 \%$ dan meningkat pada siklus II dengan rata-rata persentase ketuntasan klasikal sebesar $85,95 \%$.

Peningkatan Motivasi Belajar Siswa Menggunakan Model Make a Match pada Pelajaran IPA Kelas V. Sutarniyati (2016). Pendidikan Matematika dan Sains. dengan hasil akhir motivasi belajar IPA siswa dalam kategori sangat baik (89\%).

Penggunaan Metode Make a Match untuk Meningkatkan Hasil Belajar Siswa pada Pembelajaran IPA Materi Ciri - Ciri Khusus Makhluk Hidup Kelas VI. Asmiranti (2016). Universitas Pasundan. Hasil penelitian diperoleh bahwa penggunaan metode Make A Match sangat menunjang terhadap hasil belajar siswa pada materi ciri-ciri khusus makhluk hidup di kelas VI SDN Bukit Mulya Kecamatan Baleendah Kabupaten Bandung.

Peningkatan Motivasi Belajar Siswa dengan Menggunakan Model Kooperatif Tipe Make a Match IPA Kelas IV SD. Sakerabau (2017). Pendidikan Guru Sekolah Dasar. Hasil penelitian menunjukan bahwa model kooperatif tipe make a match dapat meningkatkan motivasi belajar siswa. Hal ini ditunjukkan oleh perolehan hasil angket pratindakan rata-rata persentase $56 \%$ kategori kurang, setelah melakukan tindakan pada siklus I rata-rata persentase menjadi $67 \%$ dalam kategori cukup, dan siklus II meningkat rata-rata persentase menjadi 87 dalam kategori sangat baik.

Peningkatan Hasil Belajar Siswa Kelas IV pada Pembelajaran IPA dengan Model Pembelajaran Make A Match Di SDN 12 Api-Api Pesisir Selatan. Saputra (2017). Konseling dan Pendidikan. Berdasarkan analisis peringkat afektif siswa Pada siklus I perubahan tanggung jawab perilaku siswa meningkat $51,0 \%$ menjadi $83,3 \%$ pada siklus kedua dan perubahan perilaku kerja sama siswa pada siklus pertama $44,1 \%$ meningkat menjadi $74,5 \%$ 
dalam siklus kedua. Hasil belajar kognitif yang pemahaman juga meningkat. Pada siklus pertama pemahaman siswa meningkat $58,8 \%$ menjadi 82,4 pada siklus kedua.

Peningkatan Hasil Belajar IPA Melalui Model Pembelajaran Kooperatif Tipe Make a Match pada Siswa Kelas 5 SD. Sektiaji (2017). JPI. Hasil penelitian antara pra siklus, siklus I dan siklus II berdasarkan (1) ketuntasan 44\%: $74 \%$ : $95 \%$, (2) skor rata-rata 64,4 : 70,0 : $79,1,3)$ skor maksimal $93: 95: 100,4)$ skor minimal $36: 48: 64$. Penelitian tersebut dikatakan berhasil karena mencapai indikator kinerja.

Penerapan Model Pembelajaran Kooperatif Tipe Make A Match Untuk Meningkatkan Hasil Belajar IPA Siswa Kelas III SDN Sobontoro 2 Boyolangu Tulungagung. Yulianto (2017). IAIN Tulungagung. Hasil penelitian menunjukkan bahwa pembelajaran IPA dengan menggunakan model Make A Match dapat meningkatkan hasil belajar siswa pada materi sumber energi, kegunaanya dan cara menghemat. Hal ini ditunjukkan dengan hasil belajar peserta didik pada tes siklus I yakni sebesar 58,33\% yang sebelumnya pada pelaksanaan pre tes hanya sebesar $39,13 \%$, dan selanjutnya pada siklus II meningkat menjadi $91,30 \%$.

Penerapan Model Pembelajaran Make a Match untuk Meningkatkan Aktivitas dan Hasil Belajar Tematik Siswa Kelas V SDN Margakaya Kecamatan Jatiagung Kabupaten Lampung Selatan. Ovandra (2018). Universitas Lampung. Hasil penelitian siklus I rata-rata keaktifan secara klasikal mencapai 76,04. Persentase keaktifan siswa mencapai $83 \%$ siswa aktif. Siklus II rata-rata keaktifan secara klasikal mencapai 82,12. Persentase keaktifan siswa mencapai $92 \%$ siswa aktif. Hasil belajar siswa siklus I rata-rata ketuntasan belajar siswa secara klasikal mencapai 75,42 dengan persentase ketuntasan siswa mencapai $75 \%$ siswa yang tuntas belajar. Hasil belajar siswa siklus II rata-rata ketuntasan belajar siswa secara klasikal mencapai 82,08 dengan persentase ketuntasan siswa mencapai 92\% siswa yang tuntas belajar.

Penerapan Metode Make a Match untuk Meningkatkan Hasil Belajar Peserta Didik pada Tema Membudidayakan Selalu Berhemat Energi Kelas IV MIN 6 Bandar Lampung. Yunita (2018). Universitas Islam Negeri Raden Intan Lampung. Hasil penelitian menunjukkan bahwa, rata-rata hasil belajar peserta didik mengalami peningkatan. Persentase ketuntasan juga meningkat. Pada pra survei persentase ketuntasan sebesar $31.43 \%$. siklus I sebesar $71.43 \%$ dan siklus II sebesar $82.86 \%$.

Upaya Meningkatkan Hasil Belajar Matematika Melalui Model Pembelajaran Kooperatif Tipe Make a Match pada Siswa Kelas III SDN Ringinsari Sleman. Ramadhan (2019). Universitas Negeri Yogyakarta. Hasil penelitian menunjukkan bahwa dengan menerapkan model pembelajaran kooperatif tipe Make A Match dapat meningkatkan hasil belajar matematika siswa kelas III SDN Ringinsari. Berdasarkan tes pada siklus I setelah menggunakan model pembelajaran kooperatif tipe Make A Match, nilai rata-rata meningkat dari 66,78 menjadi 85,89 dan persentase ketuntasan belajar meningkat dari $39 \%$ menjadi $100 \%$. Pada siklus II, dengan adanya perbaikan pada siklus I, diperoleh nilai rata-rata 90,35 dengan persentase ketuntasan belajar yaitu $100 \%$.

\section{Metode}

Jenis penelitian yang digunakan dalam penelitian ini adalah jenis penelitian PTK Kolaboratif, dimana peneliti melibatkan partisipasi guru kelas IV SDN Campuranom. Penelitian dilaksanakan di SDN Campuranom Kecamatan Bansari merupakan sekolah yang tergabung dalam Gugus Ki Hajar Dewantara UPT Dindikpora Kecamatan Bansari yang terletak di Dusun Putihan, Desa Campuranom, Kecamatan Bansari, Kabupaten Temanggung. Subjek penelitian ini adalah siswa kelas IV SDN Campuranom, Kecamatan Bansari. Jumlah siswa sebanyak 29 siswa dengan rincian 14 siswa laki-laki dan 15 siswa perempuan. Desain Penelitian Tindakan Kelas (PTK) yang digunakan penulis adalah menurut Kemmis dan Mc Taggart yaitu bentuk spiral dari Siklus I ke Siklus II. Menurut Arikunto (2010:132) Konsep penelitian Kemmis dan Mc Taggart meliputi: perencanaan (planning), pelaksanaan (acting) dan refleksi (reflection). Teknik pengumpulan data dalam penelitian ini adalah tes dan non tes. Teknik tes menggunakan instrumen butir soal sedangkan teknik non tes meliputi penilaian aspek afektif dan psikomotor diukur 
menggunakan teknik pengamatan (observasi). Indikator keberhasilan kinerja dari Penelitian Tindakan Kelas dengan model make a match mata pelajaran IPA kelas IV semester 1 SDN Campuranom dapat ditentukan dari hasil belajar yang didapatkan yaitu $80 \%$ siswa atau 23 siswa mendapatkan skor lebih besar dari Kriteria Ketuntasan Minimal (KKM) sebesar 75. Teknik analisis data yang digunakan dalam penelitian ini adalah deskriptif kuantitatif.

\section{Hasil dan Pembahasan}

Pada pelaksanaan penelitian ini akan diuraikan menjadi tiga sub bab yaitu deskripsi pra siklus, deskripsi siklus 1, dan deskripsi siklus 2. Deskripsi pra siklus menguraikan kondisi awal siswa sebelum penelitian dilakukan. Deskripsi siklus 1 dan siklus 2 menguraikan tentang kegiatan perencaaan, pelaksanaan tindakan dan observasi serta kegiatan refleksi yang dilakukan pada setiap siklus. Ketuntasan belajar prasiklus dapat dilihat melalui diagram sebagai berikut:

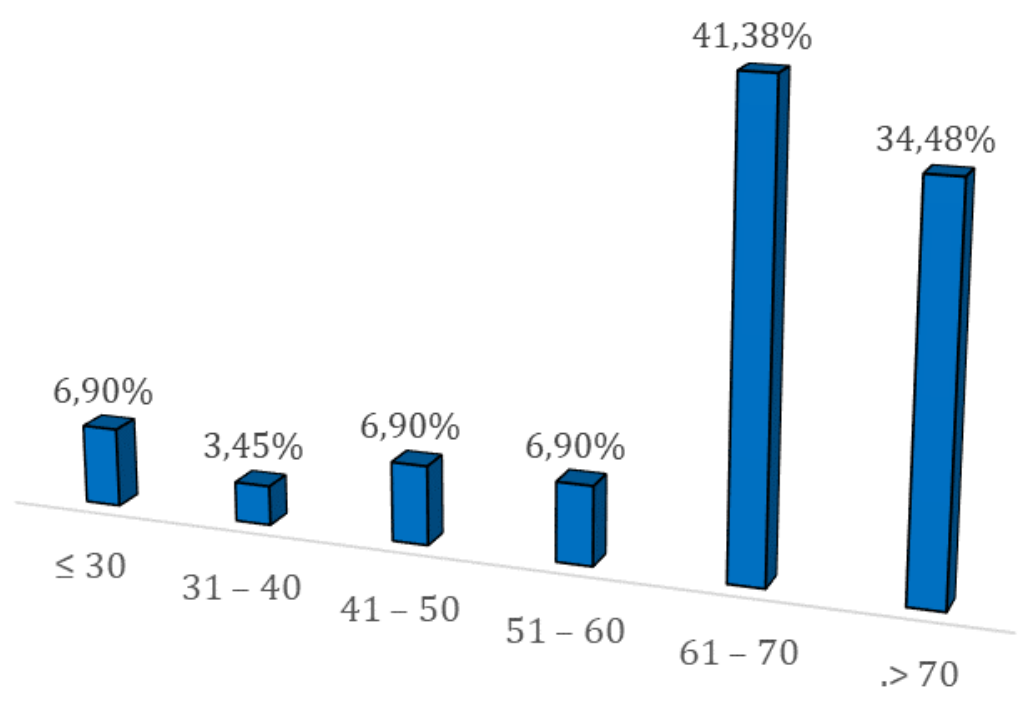

Gambar 1. Grafik Distribusi Hasil Belajar IPA Prasiklus

Berdasarkan hasil nilai ulangan harian IPA menunjukkan bahwa sebagian besar siswa memperoleh nilai di bawah $\mathrm{KKM}<70$ dapat dilihat dalam tabel berikut:

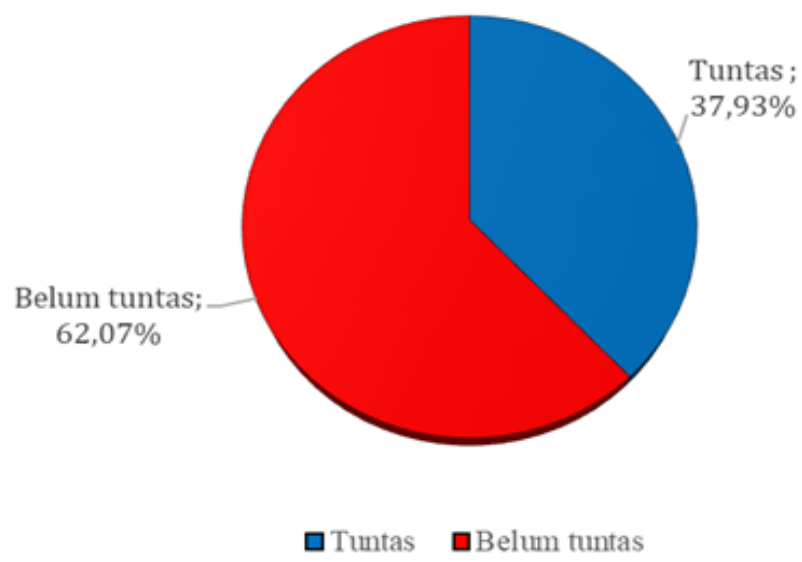

Gambar 2. Diagram Lingkaran Distribusi Hasil Belajar IPA Berdasarkan Ketuntasan Belajar Prasiklus 
Rendahnya hasil belajar IPA dipengaruhi oleh beberapa faktor antara lain penggunaan model pembelajaran yang diterapkan oleh guru. Pada saat pembelajaran IPA guru masih menggunakan metode pembelajaran ceramah sehingga pembelajaran lebih berpusat pada guru. Guru masih terpaku pada buku teks saja, siswa hanya mendengarkan dan mencatat yang disampaikan oleh guru, tahap selanjutnya siswa mengerjakan soal-soal yang terdapat dalam buku pegangan siswa. Pembelajaran yang dilakukan guru belum memberikan kesempatan kepada siswa untuk bertanya dan menjawab pertanyaan, saling berdiskusi untuk mengungkapkan pendapat.

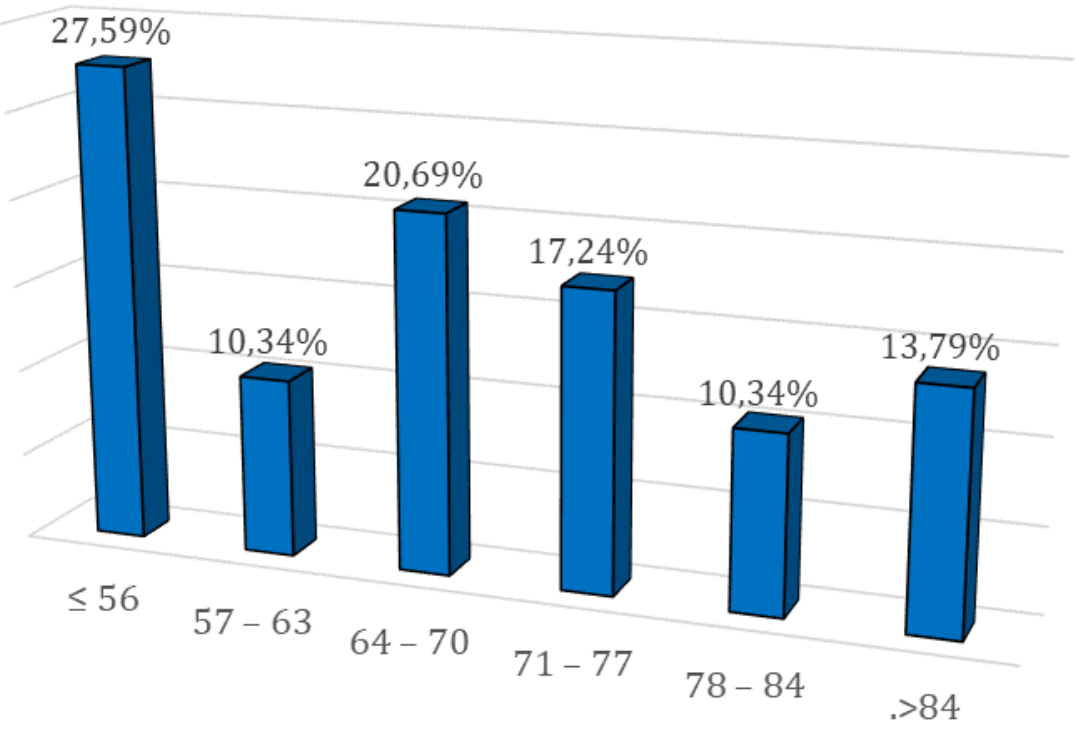

Gambar 3. Grafik Distribusi Hasil Belajar IPA Siklus 1

Ketuntasan belajar siswa siklus 1 dapat diketahui bahwa siswa yang mendapatkan nilai di atas KKM $(>70)$ sebanyak 18 siswa dengan persentase $62,07 \%$ dari jumlah seluruh siswa, sedangkan siswa yang belum mencapai KKM $(<70)$ sebanyak 11 siswa dengan persentase $37,93 \%$ dari jumlah seluruh siswa. Persentase jumlah siswa yang mencapai ketuntasan minimal masih di bawah target ketuntasan belajar kelas yaitu $80 \%$.

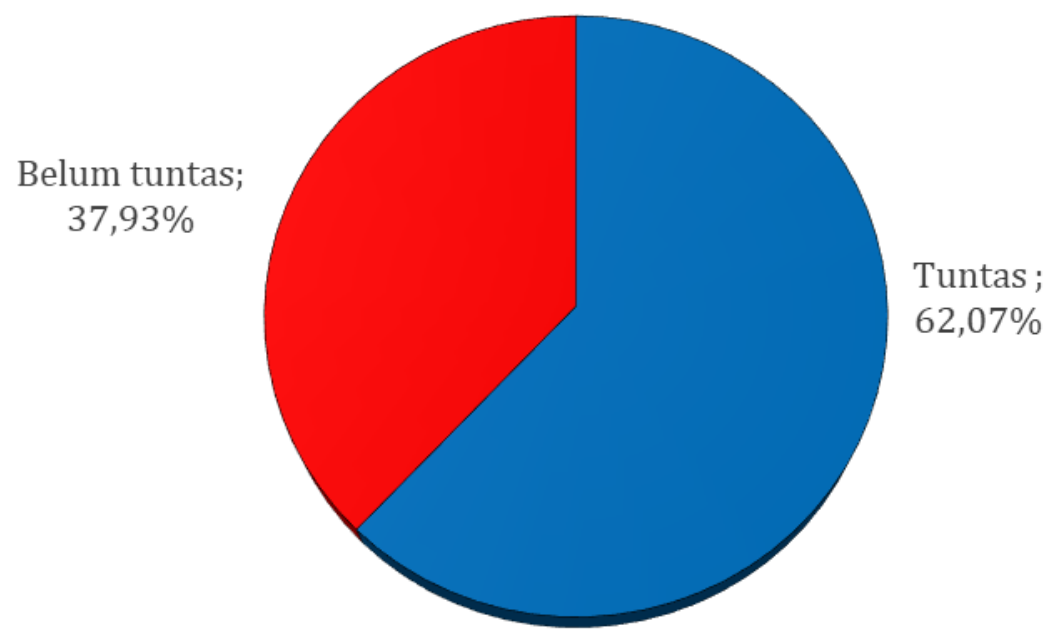

Gambar 4. Diagram Lingkaran Distribusi Hasil Belajar IPA Berdasarkan Ketuntasan Belajar Siklus 1 
Berdasarkan hasil evaluasi siklus I, dari 29 siswa mayoritas berada pada rentang nilai $\leq 56$ (27,59\%). Pada kondisi tersebut ditemukan 11 siswa (37,93\%) yang masih belum tuntas (nilai < KKM). Nilai rata - rata hasil belajar juga masih kurang dari KKM (75) yaitu 68,10 .

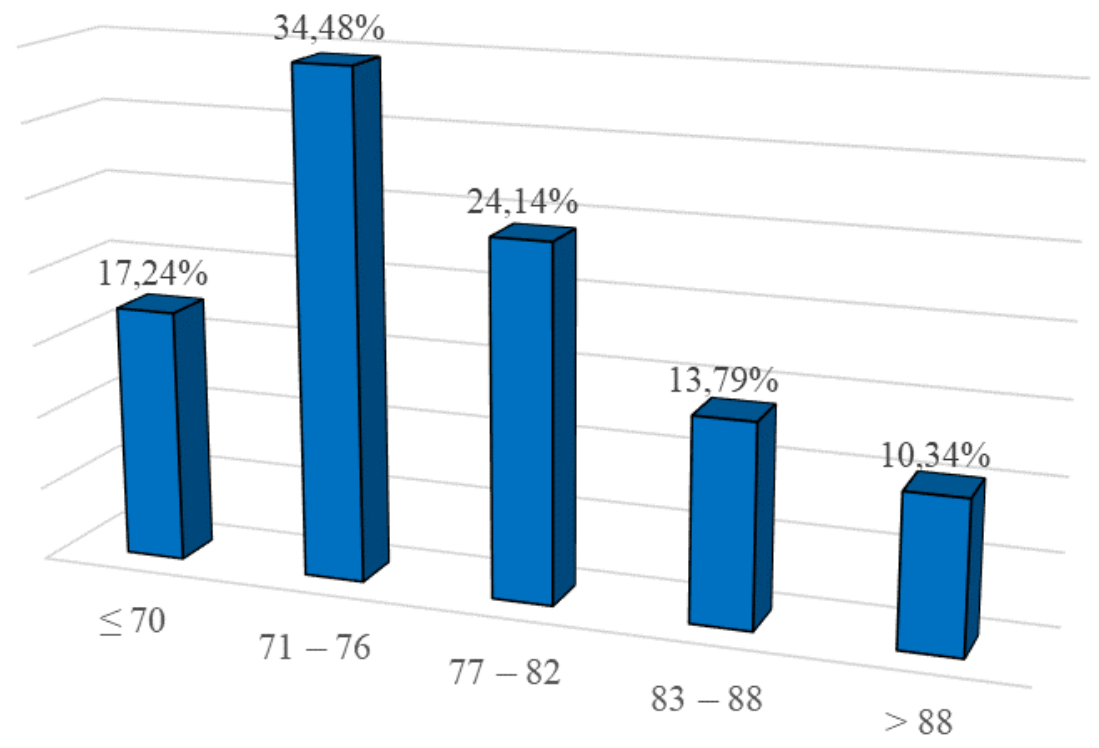

Gambar 5. Grafik Distribusi Hasil Belajar IPA Siklus 2

Ketuntasan belajar siswa siklus 1 dapat diketahui bahwa siswa yang mendapatkan nilai di atas $\mathrm{KKM}$ ( $\geq 75$ ) sebanyak 18 siswa dengan persentase $62,07 \%$ dari jumlah seluruh siswa, sedangkan siswa yang belum mencapai KKM $(<75)$ sebanyak 11 siswa dengan persentase $37,93 \%$ dari jumlah seluruh siswa. Persentase jumlah siswa yang mencapai ketuntasan minimal masih di bawah target ketuntasan belajar kelas yaitu $80 \%$.

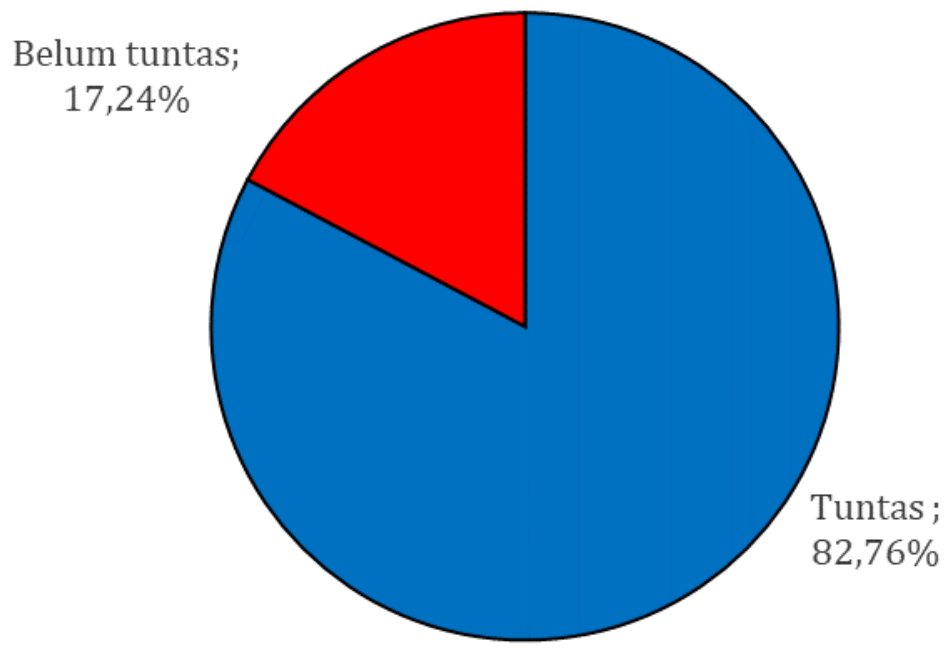

Gambar 6. Diagram Lingkaran Distribusi Hasil Belajar IPA Berdasarkan Ketuntasan Belajar Siklus 2

Berdasarkan hasil evaluasi siklus II, dari 10 siswa rata - rata berada pada rentang nilai 71 - 76 (34,48\%). Pada kondisi tersebut ditemukan 5 siswa $(17,24 \%)$ yang masih belum tuntas (nilai < KKM). Nilai rata - rata hasil belajar sudah berada di atas KKM (70) yaitu 77,07 . 
Peningkatan aktivitas dalam pembelajaran menggunakan model Make a Match berdampak pada peningkatan hasil belajar IPA. Pembelajaran dengan menggunakan model Make a Match meningkatkan aktivitas belajar siswa baik secara kognitif maupun secara fisik, proses pembelajaran menjadi lebih menyenangkan, meningkatkan pemahaman siswa terhadap materi (karena dirangsang oleh gambar-gambar yang interaktif) serta melatih motivasi siswa.

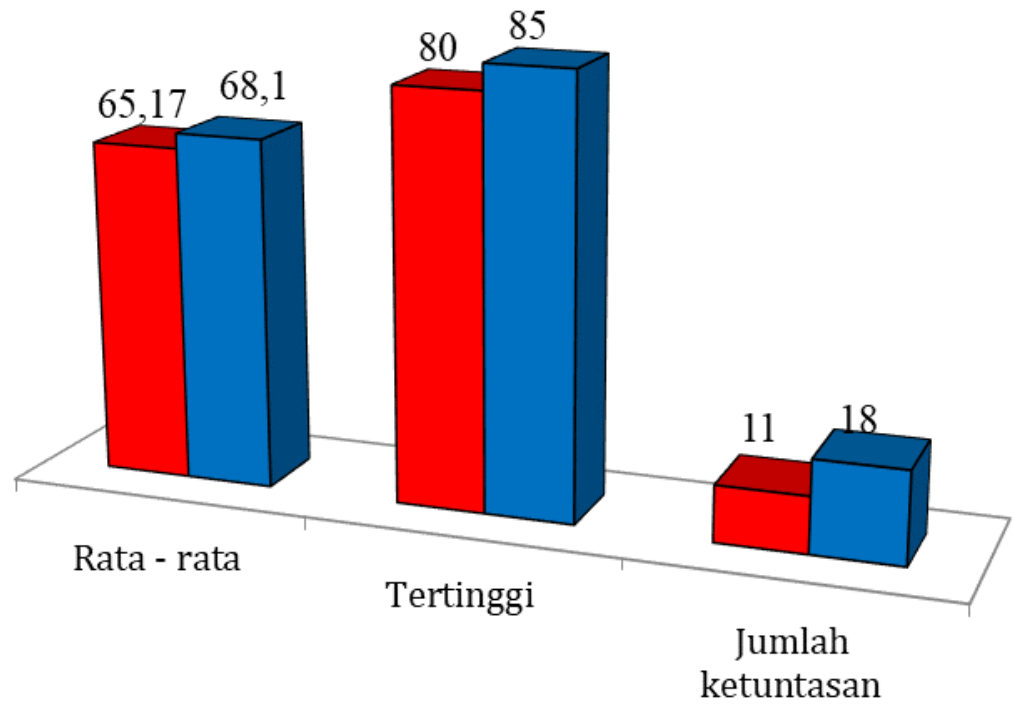

Gambar 7. Perbandingan Hasil Belajar Prasiklus dan Siklus I

Nilai rata - rata hasil belajar siklus $1>$ prasiklus $(68,1>65,17)$. Jumlah ketuntasan Siklus I juga meningkat dari 11 siswa $(32,35 \%)$ pada prasiklus menjadi $18(61,76 \%)$ siswa pada siklus I.

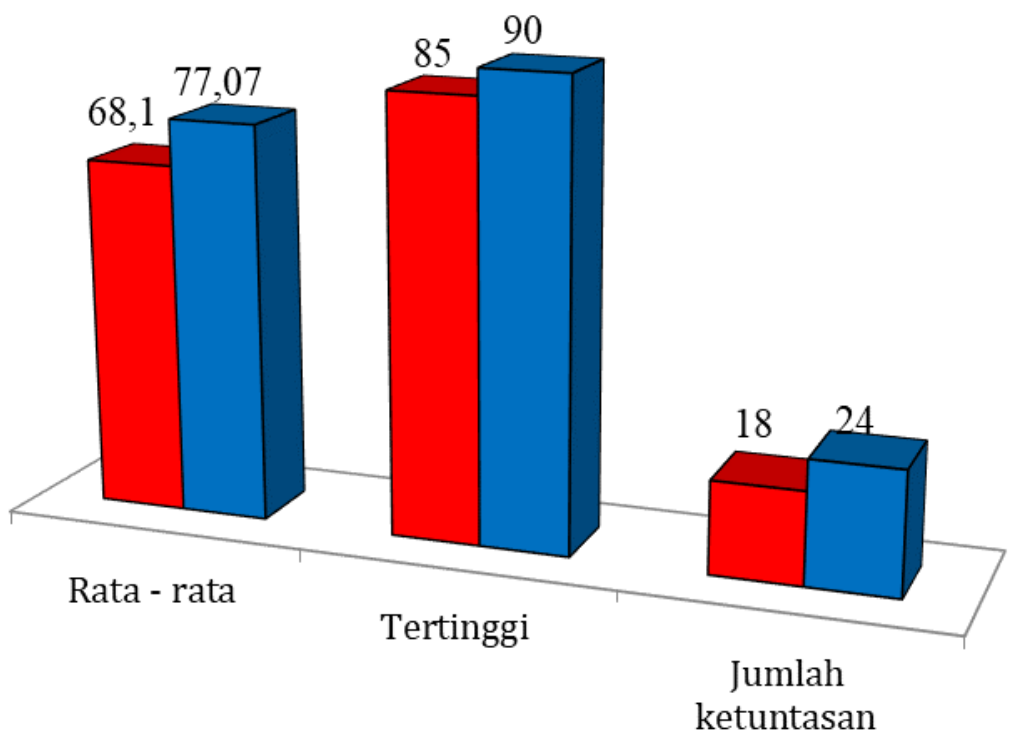

Gambar 8. Perbandingan Hasil Belajar Siklus I dan Siklus II

Berdasarkan hasil observasi yang dilakukan pada Bulan September 2019 terhadap proses pembelajaran yang dilakukan guru. Sebelum penelitian dilakukan dalam proses pembelajaran guru masih menggunakan metode konvensional yaitu metode ceramah. Model pembelajaran yang seperti ini akan membuat siswa kurang aktif, kurang kerja sama antarsiswa, dan kurang menumbuhkan ketrampilan menyampaikan pendapat dalam diskusi, 
bertanya dengan guru atau teman, menjawab pertanyaan guru, sehingga siswa pasif dalam proses pembelajaran hanya menerima apa yang disampaikan oleh guru. Hal tersebut yang menyebabkan rendahnya kerja sama dan hasil belajar IPA siswa kelas 4 SDN Campuranom. Siswa yang mencapai $\mathrm{KKM} \geq 70$, hanya 11 siswa atau $37,93 \%$, sedangkan siswa yang belum mencapai KKM terdapat 18 siswa atau 62,07\%. Berdasarkan keadaan tersebut, maka perlu dilakukan tindakan perbaikan pembelajaran untuk meningkatkan hasil belajar IPA.

Berdasarkan observasi dapat diketahui bahwa hasil observasi aktivitas guru dan aktivitas siswa pada pelaksanaan tindakan siklus 1 dan siklus 2 melalui penerapan model Make a Match telah mengalami peningkatan. Seiring dengan meningkatnya aktivitas guru, aktivitas siswa juga telah mengalami peningkatan dari siklus 1 memperoleh skor rata-rata 68,1 dengan persentase $77,07 \%$, pada siklus 2 skor rata-rata meningkat menjadi 85 dengan persentase $90 \%$.

Peningkatan aktivitas siswa dalam pembelajaran menggunakan model Make a Match berdampak pada peningkatan hasil belajar IPA. Pembelajaran dengan menggunakan model Make a Match meningkatkan aktivitas belajar siswa baik secara kognitif maupun secara fisik, proses pembelajaran menjadi lebih menyenangkan, meningkatkan pemahaman siswa terhadap materi (karena dirangsang oleh gambar-gambar yang interaktif) serta melatih motivasi siswa untuk berani tampil presentasi.

Berdasarkan uraian penelitian yang telah disajikan maka penggunaan model pembelajaran Make a Match dalam pembelajaran IPA pada kelas 4 SDN Campuranom semester 2 tahun 2019/2020 selaras dengan penelitian yang dilakukan oleh Susilowati pada mata pelajaran IPA di MI PSM Sukowiyono tahun ajaran 2016-2017 yaitu dengan menerapkan metode Make a Match menunjukkan adanya peningkatan hasil belajar siswa mulai pre test, post test siklus 1, sampai post tes siklus 2. Hal ini dapat diketahui dari nilai rata-rata persentase siswa $23,08 \%$ (pre test), meningkat menjadi $69,23 \%$ (post test siklus 1 ), dan meningkat lagi menjadi $92,31 \%$ (post tes siklus 2) dan selaras dengan penelitian yang dilakukan oleh Febriana pada mata pelajaran IPA di SD Negeri Kalibanteng Kidul 01, yaitu ketuntasan hasil belajar siswa pada siklus 1 dan siklus 2 mengalami peningkatan. Ketuntasan belajar siswa pada kondisi awal hanya 2 dari 48 siswa yang mencapai KKM. Rata-rata hasil belajar yang diperoleh pada pembelajaran IPA dengan menerapkan model pembelajaran kooperatif tipe Make A Match siklus 1 adalah 62,27 dan 26 dari 48 siswa mengalami ketuntasan belajar dengan persentase 54,16\%. Pada siklus 2 rata-rata hasil belajar adalah 71,46 dan 36 dari 48 siswa mengalami ketuntasan belajar dengan persentase $75 \%$.

\section{Simpulan dan Saran}

Berdasarkan penelitian yang dilakukan dapat disimpulkan bahwa pembelajaran IPA dengan model pembelajaran Make a Match dapat meningkatkan hasil belajar siswa kelas 4 SDN Campuranom semester 2 Tahun Pelajaran 2019/2020. Simpulan tersebut didasarkan pada rerata nilai prasiklus sebesar 65,17 dengan ketuntasan belajar $37,93 \%$ meningkat menjadi 68,1 dengan persentase ketuntasan $62,07 \%$ pada siklus 1 ; selanjutnya setelah dilakukan perbaikan pada siklus 2 rata-rata hasil belajar meningkat menjadi 77,07 dengan persentase ketuntasan mencapai $82,76 \%$. Berdasarkan hasil penelitian yang telah dilakukan, maka peneliti mengemukakan saran sehubungan dengan upaya peningkatan hasil belajar IPA dengan model pembelajaran Make a Match sebagai berikut:

Bagi Siswa: Siswa juga dapat membuat media kartu sendiri untuk belajar kelompok bersama teman diluar jam pelajaran maupun ketika belajar di rumah agar pemahaman dan daya ingat terhadap materi menjadi lebih baik. Bagi Guru: Guru hendaknya meningkatkan keterampilan mengajar melalui penerapan model pembelajaran Make a Match pada pembelajaran-pembelajaran selanjutnya karena dapat berpengaruh secara signifikan terhadap peningkatan aktivitas dan hasil belajar para siswa. Perencanaan pembelajaran hendaknya dilakukan secara baik dan lebih matang, alokasi waktu dan persiapan kelas agar tujuan aktivitas dan hasil belajar yang diharapkan dapat tercapai. Bagi Sekolah: Sekolah dapat membantu guru dalam bertukar pengalaman menerapkan model pembelajaran 
kooperatif bagi siswa pada berbagai tingkatan kelas. Kekurangan dan kelebihan pada masing - masing penerapan model di berbagai mata pelajaran dapat dievaluasi untuk bahan pengajaran lebih lanjut.

\section{Daftar Pustaka}

Asmiranti, Yayu Laras. 2016. Penggunaan Metode Make a Match untuk Meningkatkan Hasil Belajar Siswa pada Pembelajaran IPA Materi Ciri - Ciri Khusus Makhluk Hidup Kelas VI. Skripsi. Universitas Pasundan.

Jasmini. 2015. Peningkatan Kualitas Pembelajaran IPA melalui Model Make a Match Berbantuan Media Papan Flanel pada Siswa Kelas IV SDN Pudakpayung 02. Skripsi. Universitas Negeri Semarang.

Ovandra, Rizal. 2018. Penerapan Model Pembelajaran Make a Match untuk Meningkatkan Aktivitas dan Hasil Belajar Tematik Siswa Kelas V SDN Margakaya Kecamatan Jatiagung Kabupaten Lampung Selatan. Skripsi. Universitas Lampung.

Ramadhan, Alif Insan. 2019. Upaya Meningkatkan Hasil Belajar Matematika Melalui Model Pembelajaran Kooperatif Tipe Make a Match pada Siswa Kelas III SDN Ringinsari Sleman. Skripsi. Universitas Negeri Yogyakarta

Sakerebau, Elda Sanfitri. 2017. Peningkatan Motivasi Belajar Siswa dengan Menggunakan Model Kooperatif Tipe Make a Match IPA Kelas IV SD. Pendidikan Guru Sekolah Dasar, Edisi 5 (6).

Saputra, Donni. 2017. Peningkatan Hasil Belajar Siswa Kelas IV pada Pembelajaran IPA dengan Model Pembelajaran Make A Match Di SDN 12 Api-Api Pesisir Selatan. Konseling dan Pendidikan. Vol. 5 (3), 149 - 155.

Sektiaji, Irenius Emanuel. 2017. Peningkatan Hasil Belajar IPA Melalui Model Pembelajaran Kooperatif Tipe Make a Match pada Siswa Kelas 5 SD. JPI, Vol. 3 (3).

Sutarmiyati, Putri. 2016. Peningkatan Motivasi Belajar Siswa Menggunakan Model Make a Match pada Pelajaran IPA Kelas V. Pendidikan Matematika dan Sains, Edisi 34 (5).

Yulianto, Ahmat. 2017. Penerapan Model Pembelajaran Kooperatif Tipe Make A Match Untuk Meningkatkan Hasil Belajar IPA Siswa Kelas III SDN Sobontoro 2 Boyolangu Tulungagung. Skripsi. IAIN Tulungagung.

Yunita, Ema. 2018. Penerapan Metode Make a Match untuk Meningkatkan Hasil Belajar Peserta Didik pada Tema Membudidayakan Selalu Berhemat Energi Kelas IV MIN 6 Bandar Lampung. Skripsi. Universitas Islam Negeri Raden Intan Lampung 